\title{
THE CROSS-BORDER COOPERATION BETWEEN ROMANIA AND UKRAINE IN THE CONTEXT OF THE EASTERN PARTNERSHIP (EPP) AND ASSOCIATION AGREEMENTS
}

(AA) ${ }^{1}$

\author{
Mircea Brie \\ University of Oradea \\ Oradea/Romania \\ briedri@hotmail.com
}

\begin{abstract}
This paper is an analysis of the European Union's policies in the Neighborhood area at its Eastern border, with a particular focus on the special neighborhood relations developed with Ukraine. The premises of this paper are built around the idea that Romania, as an EU member state, moving within the European policies for cross-border cooperation and by using the European instruments, develops a legislative and institutional framework meant to deepen this cooperation at its border with Ukraine. The cross-border cooperation between
\end{abstract}

${ }^{1}$ This current paper is a revised and added edition of one of my contributions to the volume Iordan Gheorghe Bărbulescu (coord.), Mircea Brie, Nicolae Toderaş, Cooperarea transfrontalieră între România şi Ucraina, respectiv între România şi Republica Moldova. Oportunităţi şi provocări între 2014-2020, Tritonic, Bucureşti, 2016, 232 p. The study "Cooperarea transfrontalieră între România şi Ucraina, respectiv între România şi Republica Moldova. Oportunităţi şi provocări în perioada 2014-2020”, is part of the series "Studii de Strategie şi Politici SPOS 2015”, issued under the European Institute in Romania (IER).

The present paper is published under the framework of Jean Monnet Centre of Excelence „In and Out: Understanding the European Union Beyond Its Borders", nr. 565330-EPP-1-2015-1-RO-EPPJMO-CoE 
Romania and Ukraine has been marked by the general framework of bilateral relations, but also by the geopolitical context of the two states. Immediately after the fall of communism and the collapse of the USSR, there were difficulties in cooperation between the young Ukrainian state and the Romanian one. The relationship with Ukraine went through a period of mutual mistrust, so that the two countries have started a process of relaxation of their relations, and as a consequence, the EU has been contributing to it, as well. This cooperation has been marked by legislative and institutional changes stemming from a process of normalization and stimulation of relations with Ukraine, due inter alia to EuroAtlantic integration. The ENP also contributes to this cross-border mechanism through financial instruments, as well as legislative harmonization on both sides of the EU's external borders. The European Neighborhood and Partnership Instrument, seen as an incentive in the process of developing relations with the EU's neighbors, was thus able to create bridges at both political, socio-economic, cultural and cross-border level.

\section{Keywords}

Cross-border cooperation, Eastern Partnership, European Union, Neighborhood, Ukraine

\section{INTRODUCTION}

This paper is an analysis of the European Union's policies in the Neighborhood area at its Eastern border, with a particular focus on the special neighborhood relations developed with Ukraine. The analysis has as a starting point other research in areas such as cross-border cooperation, border studies, and neighborhood relations at the eastern border of the EU. Our own research carried out done within the study "Cooperarea transfrontalieră între România şi Ucraina, respectiv între România şi Republica Moldova. Oportunități şi provocări în perioada 2014-2020", issued under the European Institute in Romania together with Professor Iordan Gheorghe Bărbulescu and Professor Nicolae Toderaş, provide the starting point for the development and furthering this subject. 
The premises of this paper are built around the idea that Romania, as an EU member state, moving within the European policies for cross-border cooperation and by using the European instruments, develops a legislative and institutional framework meant to deepen this cooperation at its border with Ukraine. In this sense, we intend to contextualize the deepening and the necessity to change the mechanisms of the European Neighborhood Policy on the background of the European enlargement to the east of the continent, but also of the new geopolitical realities introduced by Russia's manifestations of force in the European proximity space. EU interests meet with those of Russia, often divergent. Russia's rhetoric of hostility to the West, considered expansive, has led the former Soviet states in Eastern Europe to reposition themselves, to renegotiate their relations with the EU. The European Union also faces the necessity in this context to reform its policies, including privileged relations with some partners such as Ukraine. The European enlargement to the East acquires other valences, more particular in relation to the new realities, including the internal policy of these states. The reformation and rethinking of the internal mechanisms of the European Neighborhood Policy is analyzed in analogy with the results of this policy during the various stages of the EU's relations with the two countries. The position of this state in the Eastern Partnership and then the Association Agreements were chosen as benchmarks in the analysis of the Romanian-Ukrainian cross-border cooperation. The analysis of EU official documents reveals a clear concern for it to reform its neighborhood policies, in particular those relating to the countries of Eastern Europe (Brie 2017, 123).

Another defining element in our analysis is that this cross-border cooperation must be carried out in the limit and in the spirit given by the status of the border between Romania and Ukraine as an external border of the EU. Last but not least, the conflicts in eastern Ukraine and the new dynamics of EU - Ukraine relations have been able to have a direct impact on this cross - border cooperation. 


\section{CROSS-BORDER COOPERATION AT THE EASTERN BORDER OF THE EU - A BRIEF ANALYSIS OF CONCEPTS AND CONTEXT ${ }^{1}$}

Cross-border cooperation can be defined in relation to the direct collaboration between neighboring regions found along a border, regardless of the levels at which this relationship is achieved. This cooperation can take place in all areas, among all national, regional and local authorities, involving all actors. The efficiency, reliability, authenticity and legitimacy of European construction, European integration are also related to the success of cross-border cooperation. "The basic principle of cross-border cooperation is the creation in the border areas of contractual spaces in order to find common solutions to similar problems, the state entities not defining, in relation to their peripheral collectivities, the peculiarity and specificity of the neighboring problems faced by them." (Ricq 2000, 10). The cross-border cooperation proves to be "a kind of mutual cooperation between two neighboring border regions" (Cooperare transfrontalieră 2017). This involves states, regions, administrative units from different levels and/or social groups, etc., covering all areas of everyday life and participating in the development of common programs, priorities and actions (Cooperare transfrontalieră 2017). Cross-border cooperation is favored by cultural, ethno-linguistic, historical (see the case of the Habsburg legacy in Central Europe) or the presence of national minorities. The Romanian Community of Ukraine or the Ukrainian communities in Romania are favorable elements in the process of cross-border co-operation.

1 For more details see Iordan Gheorghe Bărbulescu (coord.), Mircea Brie, Nicolae Toderaş, op. cit., p. 53-61. M ircea Brie, The European Neighborhood Policy, Mass-media and Cross-border Cooperation, in Analele Universităţii din Oradea, Seria Relaţii Internaţionale şi Studii Europene, 2009, p. 81-86; Mircea Brie, Europe from Exclusive Borders to Inclusive Frontiers: Case Study Romanian - Ukrainian Frontier, in loan Horga, Istvan Suli-Zakar (coord.), Cross-Border Partnersip with Spacial Regard to the HungarianRomanian-Ukrainian Tripartite Border, Oradea-Debrecen, 2010, p. 23-36. 
Over time, co-operation at the European border has experienced a nuancing process from the perspective of European policies. Thus, at the EU's internal borders we have the Cohesion Policy and, at the external borders, the European Neighborhood Policy (For more details, see Brie 2010, 265-280; Brie and Horga 2009, 302-318), the former being designed to reduce the gaps between the more developed and the least developed regions and Member States (For more details, see Bărbulescu 2015, 305-310), while the other brings a new approach to the relations between the European Union and its neighbors, superior to the traditional one based on simple co-operation (Europa in direct. Cooperare transfrontalieră 2017). Whether we are looking at the EU's internal level or looking at the case of its external borders, cross-border cooperation has proved to be a promoter of integration, at least at regional level. Over time, regions have often proved to be "cross-border inter-regional micro-integration models" (Ricq 2000, 11), which also deserves attention in the future on shaping policies related to the European construction process. From this point of view, territorial, cross-border or other form of co-operation is a means 'that the human being uses socially, in order to achieve their goals of increasing the quality of life' (Strategia de dezvoltare a județului Satu M are până în 2020. COM PAS 20 - Concepții și Orientare M odernă, Planificare A rmonioasă și Strategică până în 2020, Chapter 8).

The effectiveness of the cross-border cooperation depends on the co-ordination of all actors involved in this process, but also on cooperation at all levels, coupled with the existence of an appropriate legal framework. Malfunction at one of the levels may cause it to fail. Therefore, cross-border cooperation is no longer strictly the status of states, as international actors. An important role in this process is played by the local and regional administrative structures in the border areas, the development associations created by them, as well as the transnational corporations interested in promoting an economic and political environment favorable to business development (Săraru 2011, 88). In order to be successful, border areas need to cooperate with cross-border peer partners and respect the interests of each stakeholder. The European Union encourages and stimulates the development of partnerships in cross-border cooperation. The EU's interest is not only to harmoniously develop the regions on either side of the border or the security interest in the development of a neighboring 
cooperative and stable region, but also to strengthen the European spirit and identity among its citizens beyond their national-ethnic identities (Brie and Blaga 2015). 'Financial instruments and non-financial efforts (e.g. promotion of standards for enhancing competitiveness, methodological approaches, legal framework regulatory adjustment etc.) of European partners in border areas are consistent and projected for a long time' (Roșcovan, Bulat, Puntea and Miron 2010, 101). Cross-border cooperation, both at interstate, regional and local level, has been the focus of the European institutions throughout the European construction process. To make this collaboration more effective and to drive the many existing initiatives together, the creation of a normative framework has been attempted, including models of partnership and association agreements ${ }^{1}$. Under the influence of the European Neighborhood Policy, the European Union's external border concept tends to take on new forms of expression. On the one hand, we find flexibility in contacts between the two sides of the border. Such a trend is amplified through cross-border cooperation mechanisms, through Euroregions, as well as European instruments successfully implemented at the external border. On the other hand, the actions of the European Union that try to implement regional cohesion policies at its current borders, according to some analysts, prove that the Union strengthens its current external borders, taking into account, at least for the moment, the variant of slowing the process extending eastwards, without actually closing the gates ${ }^{2}$.

${ }^{1}$ See Convenția-cadru europeană privind cooperarea transfrontalieră a colectivităților sau autorităților teritoriale, Madrid, 21 mai 1980, http://conventions.coe.int/Treaty/EN/Treaties/PDF/Romanian/106-Romanian.pdf, accessed in 06.10.2017.

2 Referring to the "orange revolution" in Ukraine, the European Commissioner for External Relations and European Neighborhood Policy Benita Ferrero-Waldner said on December 1, 2004 that „la question de l'Ukraine dans l'UE n'est pas à l'ordre du jour. Mais il est clair que nous ne fermons aucune porte". See Régis Matuszewicz, Vers la fin de l'Élargissement?, in Laurent Beurdeley, Renaud de La Brosse, Fabienne Maron (coord.), L'Union Européenne et ses espaces de proximité. Entre stratégie inclusive et parteneriats removes: quell avenir pour le nouveau voisinage de I'Union?, Bruxelles, Bruylant, 2007, p. 109. 
Regarded in the regional context, the ENP appears against the backdrop of EU enlargement to the east corroborated with the change of Russia's strategy vis-àvis Eastern Europe. The region was included in the ENP and later in the PaE, and Russia perceives the area as part of its close neighborhood, a region separating it from the EU and NATO and part of what Russia called the 'Russo-Soviet identity' (Perepelytsia 2010, 105) (especially Ukraine, thus the aggressive attitude that Moscow adopted ante and post Vilnius). Under this paradigm the Ukrainians were considered to be 'Russians who speak one of the dialects of the Russian language' (Perepelytsia 2010, 105). Thus Russia has perceived and still perceives any approximation of the Republic of Moldova and Ukraine to the EU / NATO as a loss of its own influence in the area. On the other hand, Eastern Europe was seen by European leaders as a geopolitically problematic area, being located between two regional powers, but also because of the internal problems these countries faced and which affected the whole region, such as organized crime, drug trafficking, etc. (Gruszczak 2010). In consequence, the relationship developed by the EU with the Republic of Moldova and / or Ukraine was perceived in negative terms by Russia's competition, which may explain future developments in this area ${ }^{1}$.

Considering all these aspects, the cross-border cooperation was no longer a desideratum, but a necessity by which to raise the level of security from the future borders of the EU and to transform the relationship between the EU and the states of the region from a zero-sum game of a win-win type. We see thus, through the implementation of the ENP, a change of perception on the external border. In such a situation, regions and people outside Community structures can benefit from programs and policy instruments that bring them closer to EU citizens. The European Neighborhood Policy makes a significant contribution, through its territorial cooperation programs at the external border, to the

${ }^{1}$ About the East-West relation and the Russian role in this equation see a recent study by Ana Maria Costea, East versus West, When Politics collide with economics, Tritonic, 2015 
development of a more homogeneous system (Hubeny-Berlsky 2007, 317) and to 'integrated regional development'(Hubeny-Berlsky 2007, 320).

Border space involves neighborhood relations. The doctrine defines good neighborliness as a 'state of fact', 'inevitability' (the neighbors are given by history and geography), there have been peoples and states since they have generated two reactions at the frontiers: maintaining the state of security by solving conflicts and the maintenance of cooperation relations between neighboring (Apud Brie 2009, 83). Good neighborliness is closely related to the concept of 'border', even though, over time, the role of the border has changed from the barrier, becoming a little bit of a meeting point between different realities that reveal the possibility of complementarity beyond rigid conception of national sovereignty. In the cross-border area of good neighborliness a special role has 'little diplomacy' under the influence of the formal framework of relations that manifests itself through it. Positive work in the space of 'small diplomacy' creates security and trust, good neighborliness being expressed as a principle. The border regime, as defined by the literature (Niciu 1999, 246), is determined by each state under its legislation, in accordance with the agreements concluded with its neighbors (Niciu 1999, 246). States aim to ensure their good neighborhood, avoiding border conflicts, without losing sight of the attribute of border sovereignty.

Removing barriers and avoiding the emergence of new lines of division between the enlarged Europe and the new neighbors is the stated aim of the ENP since its launch (Apud Pop, Pascariu, Anglițoiu and Purcăruș, 8). Areas of cooperation are diverse: from politics to economics, from culture to security (Apud Pop, Pascariu, Anglițoiu and Purcăruș, 9). Cross-border cooperation has proven to be a priority of the European Neighborhood Policy. It aims at promoting a coherent and integrated approach to regional development, showing interest in common challenges, guaranteeing efficiency and security at the EU's external borders and encouraging cooperation at local level (Instrumentul european de vecinătate și de parteneriat - Documentul de strategie privind cooperarea transfrontalier $\breve{a ~ 2007-2013, ~}$ Cooperarea transfrontalier $\breve{~ 2007-2013 ~ 2006) . ~}$

In the case of the 2007-2013 EU financial year, the European Union's cross-border cooperation with neighboring countries, including the Republic of Moldova and 
Ukraine, was part of the European Neighborhood and Partnership Instrument. As a member of the EU, Romania was a direct partner of the two European countries within the ENP. This European policy to support the strengthening of political and economic relations with neighboring states has continued to be a priority, being included in the 'cooperation, association and partnership' (Către o nouă politică europeană de vecinătate 2015,2 ). This was in line with the text of the Treaty on European Union which states that 'the Union shall develop privileged relations with neighboring countries with a view to establishing an area of prosperity and good neighborliness based on the values of the Union and characterized by close and peaceful relations based on cooperation' (Article 8 (1)) (Către o nouă politică europeană de vecinătate 2015, 2). Over the 2007-2013 ENP, cross-border cooperation has played an important role in border regions, which are most often confronted with development gaps and socio-economic disparities.

For the 2014-2020 financial year, together with the Eastern or Southern bilateral or regional programs, the European Neighborhood Instrument, rethought in the spirit of the new EU policies, funds cross-border cooperation programs between $M$ ember States and neighboring countries (European N eighbourhood Instrument 20142020 - Programming documents 2017). These programs envisage the financing of cooperation projects between one or more Member States on the one hand and one or more partner countries and / or the Russian Federation on the other hand that run alongside them joint EU external border. Multiannual Joint Operational Programs, which regulate cooperation at a border or a border group, and which contain multi-annual measures designed to respond to a coherent set of priorities that can be implemented with EU support are envisaged. In line with the partnership principle, the actors involved jointly select actions that are likely to benefit from Union support, which are in line with the priorities and measures of the Joint Operational Program.

Through its ENP policies and instruments, the Union offers the countries of its neighborhood a "privileged relationship, based on the mutual commitment to respect and promote the values of democracy, human rights, the rule of law, good governance and the principles of a market economy, such as and sustainable and inclusive growth" (Regulamentul (U E) N R. 232/2014 A L Parlamentului European și al Consiliului din 11 
martie 2014 de instituire a unui instrument european de vecinătate, Jurnalul O ficial al U niunii Europene, $L$ 77/27 2014). The European Union is interested in the success of this neighborhood policy, which it has tried to reform, both at the level of instruments and at program level. In the new sense, EU support is used to benefit partner countries and areas involved in cross-border cooperation through a separate approach but also for the common benefit of the Union and partner countries. The new instruments and regulations give the Russian Federation access to cross-border cooperation, regional cooperation, with the participation of the Union. The Russian State can also be a part of relevant multinational programs, including co-operation in education (Regulamentul (UE) N R. 232/2014 A L Parlamentului European și al Consiliului din 11 martie 2014 de instituire a unui instrument european de vecinătate, Jurnalul O ficial al U niunii Europene, L 77/30).

The geographical eligibility of the new cross-border cooperation programs as part of the European Neighborhood Policy refers to the projects implemented in: a. The land border area covering territorial units corresponding to level 3 of the NUTS $^{1}$ or equivalent across the land borders between Member States and the other countries participating in cross-border cooperation, without prejudice to the potential adjustments necessary to ensure the consistency and continuity of the action to be taken. cooperation; $b$. the maritime border area covering NUTS level 3 territorial units or equivalent located along maritime borders between Member States and other countries participating in cross-border cooperation separated by a maximum distance of $150 \mathrm{~km}$, without prejudice to possible adjustments necessary to ensure the coherence and continuity of the cooperation action; c. a sea basin area covering NUTS 2 coastal territorial units corresponding to NUTS level 2 or equivalent, having an exit to a common maritime basin of the Member States and the other countries participating in cross-border cooperation

${ }^{1}$ See New EU Neighbourhood Policy: the European Neighbourhood and Partnership Instrument (ENPI) and the Instrument for Pre-Accession Assistance (IPA), Association of European Border Regions (AEBR), p. http://www.aebr.eu/files/publications/NeighbourhoodPolicyEN.pdf, accessed in 11.10.2017. 
(Programming of the European Neighbourhood Instrument (ENI) - 2014-2020, 11-12).

The priorities of the cross-border cooperation programs in the current formula are:

1. economic and social development;

2. the environment, public health, safety and security;

3. mobility of persons, goods and capital (Regulamentul (UE) NR. 232/2014 AL Parlamentului European și al Consiliului din 11 martie 2014 de instituire a unui instrument european de vecinătate, Jurnalul O ficial al U niunii Europene, L 77/41). Currently, the EU's neighbouring countries are less stable than they were 10-15 years ago. In the East, European partners have faced serious problems, both internal and above all because of outside peer pressure, including Russia's military pressure. The European Union has been in a position to protect its partners in the face of an increasingly expansive Russian state. The 2008 the Georgian crisis or the current conflict in the Ukraine are eloquent examples about this reality to which the EU had to adapt. In the southern area, Syria has been affected since 2011 by a civil war that has a strong impact on its neighbours. Libya and Egypt experienced deep internal crises. All this have intensified the challenges facing both the EU and its partners, enhancing economic and social pressures, massive, illegal and uncontrollable migration, further enhancing threats to international security.

The premises from which the ENP branches out are different now. In 2013, the EU reviewed its financial instruments in the context of the 2014-2020 multiannual frameworks, including the European N eighbourhood Instrument. Under this new instrument, the European Union's support for its neighbours becomes faster and more flexible, allowing for greater differentiation and incentives ('more for more' - a principle that also includes differentiating among states and stimulating the best performing ones) to the states that are the most committed to adopting reforms and making progress in consolidating deep and sustainable democracy. In spite of the financial crisis and the reduction of the EU's overall budget, the European Neighbourhood Instrument's funding amounts to $€ 15.4$ billion (Comunicare comună către Parlamentul European 2014), which highlights the 
fact that the EU prioritizes its neighbourhood. Up to $5 \%$ of the total amount of the financial envelope is allocated to cross-border cooperation programs.

Through the European Neighbourhood Instrument, which replaced the European Neighbourhood Partnership Instrument, support is given to the implementation of policy initiatives aimed at shaping the ENP, including the Eastern Partnership and the Union for the Mediterranean Sea. Neighbourhood assistance becomes more flexible and faster, reducing the complexity and duration of the programming process so as not to undermine the relevance of assistance (Instrumentul european de vecinătate 2017). In an optimistic forecast, it is considered that in the medium term the ENP will, despite recent difficulties at the EU borders, 'bring stability to the south and integrate in the East' (Apud Pristaș 2015, 61; Lippert 2008, 14).

\section{ROMANIAN-UKRAINIAN CROSS-BORDER COOPERATION. INSTRUMENTS AND RESULTS}

The cross-border cooperation between Romania and Ukraine has been marked by the general framework of bilateral relations, but also by the geopolitical context of the two states. Immediately after the fall of communism and the collapse of the USSR, there were difficulties in cooperation between the young Ukrainian state and the Romanian one. The relationship with Ukraine went through a period of mutual mistrust, so that the two countries have started a process of relaxation of their relations, and as a consequence, the EU has been contributing to it, as well. This cooperation has been marked by legislative and institutional changes stemming from a process of normalization and stimulation of relations with Ukraine, due inter alia to Euro-Atlantic integration. The ENP also contributes to this cross-border mechanism through financial instruments, as well as legislative harmonization on both sides of the EU's external borders. The European Neighbourhood and Partnership Instrument, seen as an incentive in the process of developing relations with the EU's neighbours, was thus able to create bridges at both political, socio-economic, cultural and cross-border level. 
As regards the legislative and institutional framework for facilitating crossborder cooperation, Romania has formally embraced European regulations in this area. In this context of the adoption of this legislation, bilateral and multilateral agreements have intensified. 'Various types of agreements, protocols, international treaties, conventions' have been identified to provide the widest possible regulatory framework and allow cross-border cooperation at local, inter-regional, intergovernmental and multinational level (Roșcovan, Bulat, Puntea and Miron 2010, 42). Different types of intergovernmental agreements, including conventions, protocols and treaties, continue to be part of the basic instruments needed to facilitate cross-border cooperation. The cross-border cooperation relations in Romania and Ukraine are established on the basis of the Treaty of Good Neighbourhood and Cooperation between the two states, signed in Constanta on 2 June 1997 and ratified by Romania by Law 129/1997 (Săraru $2011,89)$. On the basis of this agreement, the two countries subsequently signed several bilateral agreements with an impact on cross-border cooperation.

European policies and directives, including the ENP, converge towards the need to make the cross-border cooperation more effective and bring the exercise of competences as close as possible to citizens. Cross-border cooperation from this perspective is no longer a state policy, but it is transferred to regional, local authorities, regional associations, transnational firms, etc. The regional authorities at the Romanian borders with Ukraine and the development associations play a significant role in shaping and developing cross-border cooperation (Bărbulescu (coord.), Brie and Toderaş 2016, 122). On the basis of the Romanian legislation, regional and local public authorities in border areas 'may conclude cross-border cooperation agreements with similar structures in neighbouring states', leading to the creation of 'bodies that have legal personality according to national law', but without administrative powers ${ }^{1}$. Cross-border cooperation is therefore part of the regional development policy. From this perspective, European and national regional development policies are able to

1 Please see Legea nr. 215 din 23 aprilie $2001\left({ }^{* *}\right.$ republicată $\left.{ }^{* *}\right)\left({ }^{*}\right.$ actualizată*) administrației publice locale (actualizată până la data de 3 iulie 2008*), art. 15, (1), (3). 
stimulate cross-border cooperation, both at the level of legal regulations and in the creation of an institutional framework. This institutional framework is necessary, both at the level of coordination and in the representation of regional interests in front of national or European structures ${ }^{1}$. At the regional level three Euroregions with Romanian-Ukrainian participation were created: the Carpathian Euroregion, the Prutul de Sus Euroregion and the Lower Danube Euroregion (Bărbulescu (coord.), Brie and Toderaş 2016, 123-124; Brie, 2010, 265280).

Cross-border cooperation between Romania and Ukraine has been achieved through European instruments and mechanisms. The financial period 2007-2013 coincides with the first years after Romania's accession to the EU, and in its new quality, the Romanian state became an active and interested ENP promoter. Thus, through the ENPI, cross-border cooperation at Romania's borders with Ukraine was financed through Hungary-Slovakia-Romania-Ukraine Crossborder Operational Program; The Romania-Ukraine-Moldova Cross-Border Cooperation Operational Program, respectively the Black Sea Basin Operational Program. In addition to these programs aimed at explicit and direct support for cross-border cooperation, this was also supported by other European programs for the integration and development of the EU-Ukraine border areas.

The Operational Program for Cross-Border Cooperation Romania-UkraineRepublic of Moldova had a total budget of 138,122,693 euros for the seven years of programming at its launch. Of this amount, the EU contribution through the ENPI is $126,718,067$ euros, while the partner states have had to participate in financing projects with a total co-financing of approximately 11,404,626 euros (Programul Operațional Comun România-U craina-M oldova 2007-2013 2008, 81). The strategy of the program has been established in line with the four ENPI general objectives in the field of cross-border cooperation: 1. promoting a sustainable economy and social development; 2 . Joint solving of environmental, security and

1 Transnational regional associations become promoters of the decentralization and application of the European subsidiarity principle. An example for this can be the European Association of Border Regions (AEBR) founded in 1971. Mihai Roșcovan, Veaceslav Bulat, Mariana Puntea, Viorel M iron, op. cit., p. 15. 
public security issues or prevention and fight against organized crime; 3 . secure and efficient border management; 4. promoting "people-to-people" activities (Programul Operațional Comun România-U craina-M oldova 2007-2013 2008, 4). Against this background the specific objectives of the program were set: "1. Stimulate economic and social development in the program area and adjacent areas; 2. Addressing environmental issues in the border area and ensuring a high level of preparedness for emergencies; 3. Encouraging contacts and cooperation between the inhabitants of the border areas" (Programul Operațional Comun România-U crainaRepublica Moldova ENPI CBC 2007-2013). The eligible area of the program, covering a territory of 176.6 square kilometres, consists of regions belonging to the three neighboring states, respectively the counties of Botoşani, Galați, Iaşi, Suceava, Tulcea and Vaslui in Romania, the Odessa and Chernovtsy regions of Ukraine, and the whole territory of the Republic of Moldova. Besides these regions, the program also includes at the suggestion of the states, some adjacent regions, which 'can positively influence border co-operation'. In this category were included: "the Romanian county of Braila, the U krainian regions Ivano Frankivska, Vinniytska, ten districts in the Khmelnytska region and twelve districts in Ternopilska" (Programul O perațional Comun România-U craina-Republica M oldova 2007-2013 2017). Eligible beneficiaries of this program were "regional and local public authorities, non-governmental organizations, associations, universities, research institutes, educational / training organizations, etc." (Programul O perațional Comun România-U craina-Republica M oldova 2007-2013 2017). The variety of these eligible beneficiaries is larger and takes into account the specificity of each priority, their list being announced at each call. Applicants must be associated in a partnership, including at least two partners on both sides of the border. One of the partners must be from Romania, and at least one partner from the Republic of Moldova and / or Ukraine (Joint Operational Programme Romania-U kraine-Republic of M oldova 2007-2013. Guidelines for Grant A pplicants 2017, 14).

One year after the program was approved by the European Commission, the first call for projects (the second half of 2009) was launched. Its budget was EUR 30 
million for the first two priorities and for the third priority of EUR 5 million ${ }^{1}$. The deadline for projects submitted under Priority 3, being smaller projects, was September 28, 2009, and for the larger ones submitted on Priority 1 and Priority 2 was October 28, 2009 (Joint Operational Programme Romania-U kraine-Republic of Moldova 2007-2013. Guidelines for Grant Applicants 2017). During the project submission period, 422 applications were registered and the requested budget was 320 million euro (Ghinea and Toma 2013, 7). Of these, 112 were applicants from Moldova and 382 proposals were received from Moldovan partners compared to 247 in Ukraine and 375 in Romania (Programul O perational Comun România-U craina-M oldova 2007- 2013- proiecte deinteres strategic aflate pe agenda comună, stadiu, obstacole in implementare 2013, 5). Due to the lack of instruments, procedures, institutional changes and political changes, the evaluation period for funding applications was very high. This was basically the first exercise on this program, both for the Romanian authorities and for the Moldovan and Ukrainian partners. The first Priority 3 contracts were signed only at the beginning of 2011 and those on Priority 1 and 2 only in October 2011 (2 years after the submission of projects) (Dinu, Gamurari 2013,4). Following this first call for projects, a total of 85 winning applications totaling $€ 34,507,722.36^{2}$ were contracted to finance.

The second call for projects, which was opened for applications in November 2011, had a deadline for submission of projects January 30, 2012 (A nunt privind lansarea celui de-al doilea apel de propuneri de proiecte 2010). Up to which 1,060 applications have been registered (1.060 de note conceptuale depuse in cadrul apelului 2 pe Programul Romania-Ucraina-Republica Moldova 2012), 272 being applicants from Moldova, 141 Ukraine and 637 from Romania. On an absolute level, the number of projects doubled in the second period, indicating a growing interest of the participating countries, but at the systemic level much more was

1 With the approval of the JCC, the possibility of extending the budget for this call according to needs was foreseen, the interest identified for each priority, as well as the identification of valuable projects.

2 The complete list of the financed projects can be seen here: http://www.ro-uamd.net/proiecte-3/proiecte-contractate/proiecte-contractate-apelul-1/, accessed in 14.08.2017. 
needed (Programul Operațional Comun România-U craina-M oldova 2007- 2013proiecte deinteres strategic aflate pe agenda comună, stadiu, obstacole în implementare 2013, 5). According to the list of projects presented on the official website of the program, in the second call, 50 winning applications worth a total of EUR $35,602,720.65^{1}$ were contracted for funding, plus the co-financing part.

In addition to applications that received funding from the two calls for projects, a total of 8 major investment projects worth $44,173,979.55$ euros $^{2}$ were selected for the three program priorities, plus the co-financing part. These projects are the result of identifying major special needs by the representatives of the three partner countries. Analysing the 8 major investment projects, we find that half of them are implemented in all three Member States of the program, 3 are implemented in Romania and Moldova and only 1 in Romania and Ukraine. In 4 cases, project leaders are institutions in Romania, and in 2 cases they are from the Republic of Moldova and Ukraine. Moldova is part of 7 projects, while Ukraine is in only 5 out of 8 major investment projects. Beyond the privileged position of Romania (as a member of the EU was ensured presence in all cross-border projects), the Republic of Moldova is the main beneficiary of these investments, also taking into account the size of grants to projects involving institutions in this country. We consider, however, that an important factor contributing to this position was the privileged relationship with Romania, plus the financial support granted by the Romanian state for the implementation of these projects.

${ }^{1}$ See the full list of contracted projects as well as the financial allocations for the project, available on the program's website http://www.ro-ua-md.net/proiecte3/proiecte-contractate/proiecte-contractate-apelul-2/, accessed in 11.10.2017.

2 The list of these projects can be consulted on the official website of the program, http://www.ro-ua-md.net/proiecte-3/proiecte-contractate/proiecte-majore-deinvestitii/, accessed in 07.10.2017. 


\section{List of the major investment projects}

\begin{tabular}{|c|c|c|c|c|c|}
\hline No. & Beneficiary & Country & $\begin{array}{l}\text { Country/Region } \\
\text { of } \\
\text { implementation }\end{array}$ & $\begin{array}{l}\mathrm{N} \text { ame of } \\
\text { project/intervention }\end{array}$ & $\begin{array}{l}\text { Value o } \\
\text { the } \\
\text { European } \\
\text { financing } \\
\text { (EUR) }\end{array}$ \\
\hline 1 & $\begin{array}{l}\text { Customs } \\
\text { Service of } \\
\text { the } \\
\text { Republic } \\
\text { of } \\
\text { Moldova }\end{array}$ & MD & $\mathrm{RO}, \mathrm{MD}$ & $\begin{array}{l}\text { IMPEFO - Improve the } \\
\text { cross-border } \\
\text { cooperation between the } \\
\text { Republic of Moldova } \\
\text { and Romania in the } \\
\text { field of oil and food } \\
\text { products }\end{array}$ & $3.094 .194,60$ \\
\hline 2 & $\begin{array}{l}\text { Ministry of } \\
\text { Internal } \\
\text { Affairs } \\
\text { General } \\
\text { Inspectorate } \\
\text { for } \\
\text { Emergency } \\
\text { Situations }\end{array}$ & & RO, MD & $\begin{array}{l}\text { Improvement of Mobile } \\
\text { Service for Emergency, } \\
\text { Resuscitation and } \\
\text { Extrication (SMURD) } \\
\text { response capacity } \\
\text { through an integrated } \\
\text { system for effective } \\
\text { monitoring and } \\
\text { mitigation of disaster } \\
\text { consequences for the } \\
\text { population located } \\
\text { between the common } \\
\text { borders of Romania, } \\
\text { Ukraine and the } \\
\text { Republic of Moldova }\end{array}$ & 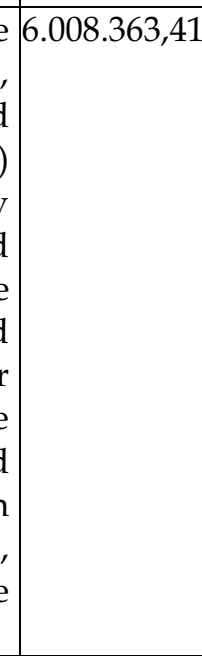 \\
\hline 3 & $\begin{array}{l}\text { National } \\
\text { Agency for } \\
\text { Mineral } \\
\text { Resources }\end{array}$ & RO & $\mathrm{RO}, \mathrm{MD}$ & $\begin{array}{l}\text { Gas pipeline for the } \\
\text { interconnection of the } \\
\text { natural gas } \\
\text { transmission system in } \\
\text { Romania and the } \\
\text { Moldovan gas } \\
\text { transmission system } \\
\text { from Iasi (Romania) - }\end{array}$ & \begin{tabular}{|l}
$7,000,000.00$ \\
\\
\\
5
\end{tabular} \\
\hline
\end{tabular}




\begin{tabular}{|c|c|c|c|c|c|}
\hline & & & & Ungheni (Moldova) & \\
\hline 4 & $\begin{array}{l}\text { Department } \\
\text { of } \\
\text { Environme } \\
\text { nt and } \\
\text { Natural } \\
\text { Resources } \\
\text { of the State } \\
\text { Regional } \\
\text { Administrat } \\
\text { ion of } \\
\text { Odessa }\end{array}$ & UA & $\mathrm{UA}, \mathrm{MD}, \mathrm{RO}$ & $\begin{array}{l}\text { Inventory, evaluation } \\
\text { and remediation of } \\
\text { sources of } \\
\text { anthropogenic } \\
\text { pollution in the Lower } \\
\text { Danube Region } \\
\text { between Ukraine, } \\
\text { Romania and the } \\
\text { Republic of Moldova }\end{array}$ & $\mid \begin{array}{r}5.181 .782,42 \\
\\
\end{array}$ \\
\hline 5 & $\begin{array}{l}\text { Ministry of } \\
\text { Economy } \\
\text { of the } \\
\text { Republic } \\
\text { of } \\
\text { Moldova }\end{array}$ & MD & $\mathrm{MD}, \mathrm{UA}, \mathrm{RO}$ & $\begin{array}{l}\text { Feasibility Study for } \\
\text { Synchronous } \\
\text { Interconnection } \\
\text { between Power Supply } \\
\text { Systems in Ukraine and } \\
\text { the Republic of } \\
\text { Moldova with the } \\
\text { ENTSO-E European } \\
\text { Continental Power } \\
\text { Transmission System }\end{array}$ & $6.360 .639,12$ \\
\hline 6 & $\begin{array}{l}\text { Ministry of } \\
\text { Transport } \\
\text { and } \\
\text { Infrastructur } \\
\text { e, Romania }\end{array}$ & & RO-UA-MD & $\begin{array}{l}\text { Cross-Border } \\
\text { Infrastructure } \\
\text { (Communications } \\
\text { Infrastructure between } \\
\text { Romania, Ukraine and } \\
\text { the Republic of } \\
\text { Moldova) }\end{array}$ & 4.700 .000 \\
\hline 7 & $\begin{array}{ll}\text { Ministry } & \text { of } \\
\text { Finance } & \text { of } \\
\text { Ukraine } & \end{array}$ & & UA-RO & $\begin{array}{l}\text { Strengthening the } \\
\text { border infrastructure by } \\
\text { modernizing the } \\
\text { customs crossing points } \\
\text { between Ukraine and } \\
\text { Romania }\end{array}$ & 3.500 .000 \\
\hline
\end{tabular}




\begin{tabular}{|l|l|l|l|}
\hline 8 & $\begin{array}{l}\text { Ministry of } \\
\text { Environme } \\
\text { nt and } \\
\text { Climate } \\
\text { Change, } \\
\text { Romania }\end{array}$ & RO-UA-MD & $\begin{array}{l}\text { Prevention and } \\
\text { protection against } \\
\text { floods in the rivers Prut } \\
\text { and Siretul de Sus by } \\
\text { implementing a modern } \\
\text { monitoring system with } \\
\text { automatic stations - } \\
\text { EAST AVERT }\end{array}$ \\
\hline
\end{tabular}

Source: Official website of the program, http://www.ro-ua-md.net

For the purpose of streamlining and facilitating implementation during the 20142020 period, a special program was created for cross-border cooperation between Romania and Ukraine, the Joint Operational Program Romania-Ukraine, fed by the EU through the European Neighbourhood Instrument (ENI). The program addresses the border area between Romania and Ukraine and will contribute to the overall objective of the European Neighbourhood Instrument: the evolution towards a region of prosperity and good neighbourliness through cross-border cooperation actions for the benefit of Member States and non-EU members in the adjoining area (Romanian Ministry of European Funds 2017). The eligible area of the program includes the Romanian counties: Botoşani, Suceava, Tulcea, Maramureş, Satu-Mare, and the Ukrainian regions: Odessa, Ivano-Frankivsk, Zakarpatska, Cernăuți. The budget of this program is $€ 66$ million (66 million total budget - of which 60 million are funded by the EU through the European Neighbourhood Instrument - ENI and 6 million euro co-financed by partner countries).

\section{CONCLUSIONS}

The relations between Romania and Ukraine have seen many changes over the last two decades. They were marked by an increasingly visible opening, generated by normalization of the bilateral relationship, but also due to the process of European integration. Upon joining the European Union, the Romanian border with Ukraine has become an external border of the EU, with all 
the consequences arising from this reality. Cross-border cooperation at the Romanian-Ukrainian border is part of the overall parameters of the European Neighborhood Policy, being supported, including financially, by the European mechanisms. Then geopolitically Ukraine has become an increasingly interesting area for the EU. The conflicts in eastern Ukraine, Russia's interference in these conflicts, have complicated this process. The EU message to Ukraine is one of openness; however cooperation has become more complex, with the Ukrainian state having to reset its internal priorities, including its regional development at the western borders.

In particular, the Romanian-Ukrainian bilateral relations have been influenced by the historical and demographic realities at the borders. The presence of a large Romanian community in Ukraine, as well as of a Ukrainian community in Romania, was often a decisive element in stimulating this cooperation.

There are still many impediments to this cross-border cooperation. They are equally related to domestic political realities and to the wider geopolitical context. At the legislative level, we often find discrepancies and gaps that prevent the implementation of initiatives promoted by the European Union. These realities are then determined by the significant differences of administrative nature, by the competences of local and regional authorities. Last but not least, we note that the process of cross-border cooperation can be influenced by the level of political will, by the general framework of bilateral relations. Such cooperation may be accompanied by legislative measures or political actions that run counter to the interests of the partners. An example of this is the new education law approved by Kiev which provides for the gradual implementation of Ukrainian education in national minority schools (including Romanian). The prospects for cross-border cooperation depend then on factors external to the bilateral relationship, the positions and new geopolitical realities. 


\section{REFERENCES}

- Anunț privind lansarea celui de-al doilea apel de propuneri de proiecte [A nnounce regarding the second call for projects proposals], Programul Operațional Comun România - Ucraina - Republica Moldova 2007 - 2013 (The Common Operational Programme Romania-Ukraine-Moldova 2007-2013), http://www.mdrap.ro/userfiles/ro_uk_mo_anunt_apel2.pdf, accessed in 11.10.2017.

- Bărbulescu, Iordan Gheorghe (coord.); Brie, Mircea and Toderaş, Nicolae. 2016. Cooperarea transfrontalieră între România şi Ucraina, respectiv între România şi Republica Moldova. Oportunități şi provocări între 2014-2020 [Crossborder cooperation between Romania-U kraine, Romania-Republic of M oldova 2014-2020], Tritonic, Bucureşti, 2016

- $\quad$ Bărbulescu, Iordan Gheorghe. 2015. Noua Europă. Identitate şi model European [The N ew Europe. Identity and the European model], Polirom, 2015

- $\quad$ Brie, Mircea and Blaga, Daniela. 2015 Identity rematch in the European space, in Cultural Diplomacy at the East and West Borders of the European U nion, 2015.

- Brie, Mircea, Horga, Ioan. 2009. The Romanian-U kranian Cross-Border Cooperation an The European Instruments, în U craina- Romania- M oldova: aspecte istorice, politice si culturale ale relatiilor in contextul proceselor europene contemporante, vol. 3, Cernăuți, 2009, p. 302-318

- Brie, Mircea. 2009. The European Neighborhood Policy, M ass-media and Cross-border Cooperation, in Analele Universității din Oradea, Seria Relații Internaționale şi Studii Europene, 2009, p. 81-86

- Brie, Mircea. 2009. The European Neighborhood Policy, M ass-media and Cross-border Cooperation, in Analele Universității din Oradea, Seria Relații Internaționale și Studii Europene, 2009, p. 81-86.

- $\quad$ Brie, Mircea. 2010. Europe from Exclusive Borders to Inclusive Frontiers: Case Study Romanian - U krainian Frontier, in Ioan Horga, Istvan Suli-Zakar (coord.), Cross-Border Partnersip with Spacial Regard to the Hungarian-Romanian-U krainian Tripartite Border, Oradea-Debrecen, 2010, p. 23-36.

- $\quad$ Brie, Mircea. 2010. European Instruments of Cross-border cooperation. Case study: the Romanian-U krainian border, in Identités, citoyennetés et démocratie, 20 ans après, sous la direction de Fabienne Maron, Grzegorz Pozarlik, Editions Bruylant, Bruxelles, 2010, p. 265-280 
- $\quad$ Brie, Mircea. 2017. A N ew European N eighbourhood Policy toward U kraine and the Republic of Moldova in the Context of the Eastern Partnership (EaP) and the A ssociation A greements (A A), in Studii Europene, no. 10, Chisinău, 2017, p. 123-155. - Către o nouă politică europeană de vecinătate [Towards a new European N eighbourhood Policy], Document comun de consultare, Comisia Europeană, Înaltul Reprezentant al Uniunii Europene pentru Afaceri Externe și Politica de Securitate, Bruxelles, 4.3.2015 JOIN(2015) 6 final, http://ec.europa.eu/enlargement/neighbourhood/consultation/consultation_r omanian.pdf, accessed in 11.10.2017.

- $\quad$ Comisia Europeană, Înaltul Reprezentant al Uniunii Europene pentru Afaceri Externe și Politica de Securitate, Comunicare comună către Parlamentul European, Consiliu, Comitetul Economic și Social European și Comitetul Regiunilor. Politica de vecinătate la răspântie: punerea în aplicare a politicii europene de vecinătate în 2013, [Common Communication to the European Parliament, the Council, The European Ecomonic and Social Committee] EUR-Lex, Access to European Union law, http://eur-lex.europa.eu/legalcontent/RO/TXT/PDF/?uri=CELEX:52014JC0012\&from=RO, accessed in 12.10.2017.

- $\quad$ Convenția-cadru europeană privind cooperarea transfrontalieră a colectivităților sau autorităților teritoriale [The European Conventioin regarding the crossborder cooperation of colectivities or teritorial authorities], Madrid, 21 mai 1980, http://conventions.coe.int/Treaty/EN/Treaties/PDF/Romanian/106Romanian.pdf, accessed in 06.10.2017.

- Cooperare transfrontalieră [Crossborder Cooperation], http://transeco.ecosv.ro/cooperare_trans_ro.htm, accessed in 22.08.2017.

- Costea Ana Maria. 2015. East versus West, When Politics collide with economics, Tritonic, 2015

- Dinu, Dragos;; Gamurari, Ludmila. 2013. The Joint O perational Program Romania - U kraine - Republic of Moldova. Current challenges and further developments, Policy Memo, nr. 36, CRPE, A new framework for better cooperation: Romania-U kraine-M oldova, Centrul Român de Politici Europene, February 2013, p. 4, http://www.crpe.ro/wp-content/uploads/2013/02/Trilaterala-romaniaucraina-ok.pdf, accessed in 12.10.2017.

- $\quad$ EUR-Lex, Access to European Union law, Instrumentul european de vecinătate și de parteneriat - D ocumentul de strategie privind cooperarea transfrontalieră 2007-2013 [The European Instrument of N eighbourhood and Partnership- The Strategic Document regarding the crossborder cooperation 2007-2013], Crossborder 
cooperation 2007-2013-Sinthesis, http://eur-lex.europa.eu/legalcontent/RO/TXT/HTML/?uri=URISERV:r17104\&from=RO, accessed in 11.10.2017.

- EUR-Lex, Access to European Union law, Regulamentul (UE) NR. 232/2014 A L Parlamentului European și al Consiliului din 11 martie 2014 de instituire a unui instrument european de vecinătate [EU Rule No.232/2014 of the European Parliament and of the Council frim $11 \mathrm{M}$ arch 2014 regarding the European instrument of Neighbourhood], Jurnalul Oficial al Uniunii Europene, L 77/27, 15.03.2014, http:/ / eur-lex.europa.eu/legalcontent/RO/TXT/?uri=uriserv:OJ.L_.2014.077.01.0027.01.RON, accessed in 30.09.2017.

- Europa in direct. Cooperare transfrontalieră [Europelive. Crossborder cooperation], http://europaindirect.ecosv.ro/cooperare_trans.htm, accessed in 14.09.2017.

- $\quad$ European Union, External Action, European Neighbourhood Instrument 2014-2020 - Programming documents, http:/ / eeas.europa.eu/enp/documents/financing-the-enp/index_en.htm, accessed in 19.09.2017.

- Ghinea, Cristian; Toma, Bianca. 2013. Bune practici în relația România Republica M oldova. M odele de parteneriat [Good practices regarding the relationship between Romania and the Republic of M oldova. Partnership models], Policy Memo, nr. 47, CRPE, September 2013, http://www.crpe.ro/wpcontent/uploads/2013/10/policy-memo-47-crpe-Moldova-Bune-Practici-raportfinal.pdf, accessed in 11.10.2017.

- Gruszczak, Artur. 2010. „The securitization of the Eastern borders of the European Union. Walls or bridges?', (paper to the UACES 40th Annual Conference Exchanging Ideas on Europe: Europe at a Crossroads, Bruges, 6-8 September 2010), http://www.uaces.org/pdf/papers/1001/gruszczak.pdf accessed in 11.10.2017

- $\quad$ Hubeny-Berlsky, Annabelle. 2007. Le financement de la PEV - la réponse proposée (1), in Laurent Beurdeley, Renaud de La Brosse, Fabienne Maron (coord.), L'U nion Européenne et ses espaces de proximité. Entre stratégie inclusive et parteneriats removes: quell avenir pour le nouveau voisinage de I'U nion?, Bruxelles, Bruylant, 2007.

- Instrumentul european de vecinătate [The European Neighbourhood Instrument], European Moldova, Recourses Centre 'DIALOG-PRO', 
http://infoeuropa.md/instrumentul-european-de-vecinatate/, accessed in 11.09.2017.

- Joint Operational Programme Romania-U kraine-Republic of M oldova 20072013. Guidelines for Grant A pplicants, Priority 1 - Towards a more competitive border economy and Priority 2 - Environmental challenges and emergency preparedness, http://www.mdrap.ro/dezvoltare-regionala/-2257/ programe-de-cooperareteritoriala-europeana/-3696, accessed in 11.10.2017.

- $\quad$ Legea $\mathrm{nr} .215$ din 23 aprilie $2001\left(^{(* *}\right.$ republicată $\left.{ }^{* *}\right)\left({ }^{*}\right.$ actualizată$\left.{ }^{*}\right)$ administratiei publice locale [Law no 215 from 23 A pril 2001 of the Local Public Administration] (updated till 3 July 2008*)

- Matuszewicz, Régis. 2007. Vers la fin de l'Élargissement?, in Laurent Beurdeley, Renaud de La Brosse, Fabienne Maron (coord.), L'U nion Européenne et ses espaces de proximité. Entre stratégie inclusive et parteneriats removes: quell avenir pour le nouveau voisinage de I'U nion?, Bruxelles, Bruylant, 2007.

- Ministerul Fondurilor Europene/România, http://www.fonduriue.ro/ro-ua\#contact-am-ro-ua, accessed in 19.10.2017.

- $\quad \quad \quad \quad$ ew EU N eighbourhood Policy: the European N eighbourhood and Partnership Instrument (ENPI) and the Instrument for Pre-Accession Assistance (IPA), Association of European Border Regions (AEBR), p. 5, http://www.aebr.eu/files/publications/NeighbourhoodPolicyEN.pdf, accessed in 11.10.2017.

- Niciu, Marțian. 1999. Drept internațional public [Internatinal Public Law], Ed. Servosat, 1999.

- $\quad$ Perepelytsia, Grygoriy. 2010. 'Capacity of instruments for development of mutually beneficial relations in the format 'Uraine-Visegrad Plus,' volume of the International Conference: U kraine and the Visegrad Four: Towards a M utually Beneficial Relationship, May 13-14, 2010.

- $\quad$ Policy Memo, nr 46, Romanian Centre for European Policies, August 2013, http://www.crpe.ro/wp-content/ uploads/2013/08/Policy-Memo-CooperareRegionala-FINAL.pdf accessed in 20.09.2017.

- $\quad$ Policy Memo, nr 46, Romanian Centre for European Policies, August 2013, http://www.crpe.ro/wp-content/uploads/2013/08/Policy-Memo-CooperareRegionala-FINAL.pdf accessed in 11.10.2017.

- Pop, Adrian; Pascariu, Gabriela; Anglițoiu, George and Purcăruș, Alexandru. România și Republica M oldova - între Politica Europeană de Vecintate și perspectiva extinderii U niunii Europene [Romania and the Republic of M oldova-between the European Neighbourhood Policy and the enlargement of the European Union], 
European Institute from Romania - Studii de impact III, , http://www.ier.ro/sites/default/files/pdf/Pais3_studiu_5_ro.pdf, accessed in 11.10.2017.

- $\quad$ Pristaș, Alina Ioana. 2008. Implicarea României în Politica de vecinătate a Uniunii Europene [the Engagement of Romania within the European N eighbourgood Policy], PhD thesis, Babeș-Bolyai University, Cluj-Napoca, 2015, Barbara Lippert, European Neighbourhood Policy: Many reservations - some progress - uncertain prospects, June 2008

- $\quad$ Programming of the European N eighbourhood Instrument (ENI) - 2014-2020, Programming document for EU support to EN I Cross-Border Cooperation (2014-2020), http://eeas.europa.eu/enp/pdf/financing-the-enp/cbc_20142020_programming_document_en.pdf, accessed in 11.10.2017.

- Programul Operational Comun România-U craina-M oldova 2007-2013 [The Common $O$ perational Programme Romania-U kraineM oldova 2007-2013] (2008 version), , http://www.mdrl.ro/_

documente/coop_teritoriala/granite_externe/ro_uk_mo/POC\%20Ro-UaMd\%2029\%20feb\%20romana.pdf, accessed in 11.10. 2017.

- $\quad$ Programul Operațional Comun România-U craina-Republica M oldova 20072013 - finanțat din ENPI [The Common Operational Programme Romania-UkraineM oldova 2007-2013-financed through ENPI], http://www.mdrap.ro/dezvoltareregionala/-2257/ programe-de-cooperare-teritoriala-europeana/-3696, accessed in 11.10.2017.

- Programul Operațional Comun România-U craina-Republica M oldova ENPI CBC 2007-2013 [The Common O perational Programme Romania-U kraine-M oldova 2007EN PI CBC 2013], Secretariatul Tehnic Comun, Biroul Regional pentru Cooperare Transfrontalieră Suceava pentru Granița România-Ucraina, http://www.brctsuceava.ro/ pagini/ programul-operational-comun-enpi-cbc2007-2013/ro-ua-md/obiective-i-priorit-i-1.html, accessed in 11.10.2017

- $\quad$ Ricq, Charles. 2000. Manual de cooperare transfrontalieră pentru uzul colectivităților locale și regionale în Europa [Crossborder cooperation manual for the use of local and regional colectivities in Europe)], the $3^{\text {rd }}$ edition, Bucharest, 2000.

- Roșcovan, Mihai; Bulat, Veaceslav; Puntea, Mariana and Miron, Viorel. 2010. Ghid de cooperare transfrontalieră [Crossborder Cooperation Guide], Second edition, Chișinău, 2010.

- Săraru, Cătălin-Silviu. 2011. „Considérations sur les accords de coopération transfrontalières entre les unités administratives-territoriales limitrophes des zones 
frontalières de la Roumanie et les structures similaires dans les pays voisins', in 'Curentul Juridic' nr. 2(45)/2011.

- $\quad$ Strategia de dezvoltare a judetului Satu Mare până în 2020. COM PAS 20 Concepții și O rientare M odernă, Planificare A rmonioasă și Strategică până în 2020 [The Development Strategy of Satu M are county until 2020. COM PAS 20-Cencepts and Modern Direction. Harmonious and Strategic Planning until 2020], Chapter 8. Crossborder Cooperation, file:/ / C:/Documents\%20and\%20Settings/MirceaB/My\%20Documents/Downl oads/CAPITOLUL $\% 208 \% 20$ -

\%20COOPERARE\%20TRANSFRONTALIERA\%CC\%86_1.pdf, accessed in 04.10.2017. 